\title{
Level of Shariah Compliance in the Operation of Islamic Banks in Bangladesh: An Empirical Study
}

\author{
Md. Rezaul Karim*
}

Samia Afrin Shetu ${ }^{* *}$

Received: 20.06 .2020

Accepted: 05.11.2020

DOI: $10.25272 /$ ijisef.755679

Type: Research Article

\begin{abstract}
This paper has tried to assess the level of Shariah compliance in the operation of the Islamic Banks in Bangladesh. The data were collected from questionnaire survey on 400 respondents from six Islamic banks regarding banking operations and from personal interview with bank officials \& regulators of the banks in the month December 2019. Other data were attained from different journals, books, Qur'an, Sunnah and the websites of the sample banks. Descriptive statistics are used to analyze the data. Although most of the Islamic banks have policy for shariah deposit, they offer fixed profit rate which is violation of shariah. In case of investment, significant non-compliance is found in Musharakah contact although moderate level of compliance is found in Mudarabah, Ijarah and Quard Hasanah contracts. Highest level of non-compliance is found in shariah based annual audit. The underlying reasons for the non-compliance are the absence of mandatory Shariah guidelines, lack of Shariah scholarly officials, dual audit compliance, absence of penalties for non-compliance and some other external factors. If the Central bank and other regulatory bodies are concerned enough to form a uniform guideline for all the Islamic banks operating in Bangladesh, it will be easier for the Islamic banks to comply with Shariah. This is the sole study that deals with different areas of operations in the Islamic Banks to assess the shariah compliance. It has incorporated both survey and interview findings to assess the real picture.
\end{abstract}

Keywords: Shariah, Islamic bank, Islamic financial institutions, Shariah compliance, Bangladesh

Jel Codes: G10, G21, G28, G38

\footnotetext{
* Asst. Prof., Department of Accounting \& Information Systems, University of Dhaka, reza.ais@du.ac.bd, ORCID: 0000-0002-6207-3542

${ }^{* *}$ Lecturer, Department of Tourism \& Hospitality Management, University of Dhaka, samia.thm@du.ac.bd, ORCID: 0000-0003-0665-602X
} 


\section{Introduction}

Shariah is an Arabic word which means following the Islamic rules and regulations that are provided with Qur'an \& Sunnah (Omar, 2010). Shariah is the operational foundation for Islamic Financial Institutions (IFI) such as Islamic banks and if anybody or any institution is not following Shariah in all its activities, he/she will not be treated as Muslim and that institution will not be regarded as Islamic institutions (Al-Quran, 5:44).

The main differentiating point between Islamic and conventional banks is the interest (riba) which is strictly prohibited in Islam. Islamic banks follow profit and loss sharing (PLS) system to comply with shariah. It offers Mudarabah (which is trust based financing), Musharakah (which is participatory based financing) and Murabaha (which is mark-upbased financing) based contract to ensure profit instead of interest (Miah \& Suzuki, 2020).

The definite characteristics of Islamic banking are the prevalence of Shariah supervisory board that consists of Shariah scholars (Abbas et al., 2009). This board affects the operational activities of Islamic banks according to Abbas et al. (2009) and Iqbal et al. (1998). Shariah experts play a substantial character in the practice of Islamic banks (Siddiqi, 2006a) although shariah based governance has several limitations e.g. lack of experts, dual compliance etc. (Siddiqi, 2006a). The followings are some concepts from Al Baraka bank, Lebanon (2004) that defines the Islamic banks' main characteristics:

- Prohibition of usury or interest: Interest is basically known as usury or riba which is strictly forbidden for Islamic banks either in case of giving or receiving. Islamic banks are not only strictly prohibited from discharging any riba or interest payments but also disallowed to involve in speculation. They mainly run business based on profit-loss sharing (Choudhury \& Hoque, 2006).

- Ethical Standards: Islamic banks follow an ethical standard in case of choosing investment sector because it is their duty to investigate where it investing in, what goods it generates, what services it supplies and finally what is the impact of it on the society and the economy.

- Moral/social values: Islamic banks will not work only for profit. It should care and support the poorer section of the community by profit free loan, donation, grants etc. for their betterment.

- Liability and business risk: The Islamic Shariah supports the concept of fairness and justice- that all the parties involved in the contract shall share the profit as well as risk among them. The profit will be shared based on the predetermined rate and the risk. 
The growth in Islamic finance and banking has been unrivalled not only in Muslim countries but also in western countries (Khan \& Bhatti, 2008). The banking industry that started on a modest scale since its inception in the mid-1970s has shown a rapid expansion and evolution over the past five decades. It is in fact one of the fastest growing industries, having posted double-digit annual growth rates for almost 50 years (Bangladesh bank, 2020).

Islamic bank is a socially responsible organization that conducts business by using society's resources (Omar and Haq, 1996). But it is not possible for a sound person to consider that the Islamic bank or banking system is a benevolent organization that merely have apprehension for the people being unprivileged or to offer monetary support as requested (Rosly and Bakar, 2003). In the same way, it is incompatible for the Islamic banks management to put emphasis on profit maximization policy only by neglecting other public obligations. As an alternative, Islam aims for getting a sense of balance between social objectives and profit. If Islamic banks are not capable of providing adequate profits to shareholders and depositors who have trusted them with money, it will be injustice to them. Besides, they are not assumed to make extreme earnings at the cost of customers or neglecting and undermining their social accountability and obligations to their different Stakeholders (Chapra, 1985; Ahmad, 2000).

\section{Emergence of Islamic Banking Concept in Bangladesh}

Bangladesh is an eminent center for Islamic banking within south Asia. Here Islamic banking concept was first initiated in 1983 by founding Islami bank Bangladesh Ltd. as a commercial private bank with the ingenuity of few Muslim entrepreneurs and under the guidance of intercontinental Islamic institutions and Bangladesh government. After foundation, the number of Islamic banks in Bangladesh has increased enormously with the massive retaliation from the Muslim people of Bangladesh. The second founding Islamic bank was Al-Baraka Bank Bangladesh Ltd. This has been lately rebranded as ICB Islamic Bank Ltd. From 1995, a great number of commercial banks that are conventional in nature initiated to start Islamic banking by introducing Islamic banking branches or windows such as prime bank (BMB Islamic, 2011; Sarker, 2005;). Till June 2020, eight full-fledged Islamic banks having branches of 1274, 9 conventional banks with 19 Islamic banking branches and 12 conventional banks with 155 Islamic banking windows are providing Islamic banking services in Bangladesh (Bangladesh Bank, 2020). 
Table 1. Recent Information about Islamic Banks in Bangladesh

\begin{tabular}{|c|c|c|}
\hline Category & Bank name & $\begin{array}{l}\text { Total number of branch/ } \\
\text { windows }\end{array}$ \\
\hline A) & Full-fledged Islamic Banks (branches) & 1278 \\
\hline 1 & Islami Bank Bangladesh Limited & 358 \\
\hline 2 & First Security Islami Bank Limited & 189 \\
\hline 3 & Al-Arafah Islami Bank Limited & 184 \\
\hline 4 & Social Islami Bank Limited & 161 \\
\hline 5 & EXIM Bank Limited & 131 \\
\hline 6 & Shahjalal Islami Bank Limited & 132 \\
\hline 7 & Union bank Limited & 90 \\
\hline 8 & ICB Islamic Bank Limited & 33 \\
\hline B) & $\begin{array}{l}\text { Islamic banking branches of } \\
\text { conventional banks }\end{array}$ & 19 \\
\hline 1 & The City bank Limited & 1 \\
\hline 2 & AB Bank Limited & 1 \\
\hline 3 & Dhaka Bank Limited & 2 \\
\hline 4 & Premier Bank Limited & 2 \\
\hline 5 & Prime Bank Limited & 5 \\
\hline 6 & Southeast Bank Limited & 5 \\
\hline 7 & Jamuna Bank Limited & 2 \\
\hline 8 & Bank Alfalah Limited & 1 \\
\hline C) & $\begin{array}{l}\text { Islamic banking windows of } \\
\text { conventional banks }\end{array}$ & 156 \\
\hline 1 & Sonali Bank Limited & 58 \\
\hline 2 & $\begin{array}{l}\text { Janata Bank Limited (has permission } \\
\text { but not yet started) }\end{array}$ & 0 \\
\hline 3 & Agrani Bank Limited & 15 \\
\hline 4 & Pubali Bank Limited & 12 \\
\hline 5 & Trust Bank Limited & 15 \\
\hline 6 & Standard Bank Limited & 5 \\
\hline 7 & Bank Asia Limited & 5 \\
\hline 8 & Standard Chartered Bank & 1 \\
\hline 9 & NRB Global Bank & 25 \\
\hline 10 & Mercantile Bank & 10 \\
\hline 11 & Midland Bank & 2 \\
\hline 12 & NRBC Bank & 8 \\
\hline
\end{tabular}

Source: Websites of the banks (Accessed October 25, 2020)

According to Nabi, Islam, Bakar, Akter (2015), Approximately 20\% of the market share in banking sector is controlled by the Islamic banks although current market share has 
risen to around 25\% (The Financial Express, February 18, 2020; Bangladesh Bank, 2020). However, Shariah compliance system can hardly be known fully as no separate law has been introduced in regards of performing Islamic banking activities in Bangladesh. The regulatory authority, Bangladesh bank regulates the activities of not only conventional banks but also the Islamic banks. The central bank has placed Shariah compliance guidelines for the functions of Islamic banks in Bangladesh in 2009. The guideline forms severe criteria for the competencies as well as qualities of a member of a Shariah supervisory council (Bangladesh Bank, 2014).

Bangladesh bank does not contain a board regarding Shariah to oversee Bangladeshi Islamic banks. However, there is a Central Shari'ah Board for Islamic Banks of Bangladesh (CSBIB) which is a private non-corporate organization. CSBIB comprises almost all the Islamic banks in Bangladesh as their member. It is composed of a great number of well-known scholars within Bangladesh and holds habitual meetings regularly to talk about Shariah issues associated with the Islamic banking sector. It also conducts research and publishes journals and books to provide guidance to its members (BMB Islamic, 2011). Nevertheless, Shariah resolutions provided by CSBIB anyway are not obligatory rather than voluntary, it only gives advisory services. However, due to reputation risks (e.g. non-compliance), Islamic banks do not contravene the guidance provided by the CSBIB (Abdullah \& Rahman, 2017).

Figure 1. Shariah Governance Structure of Islamic Banks in Bangladesh

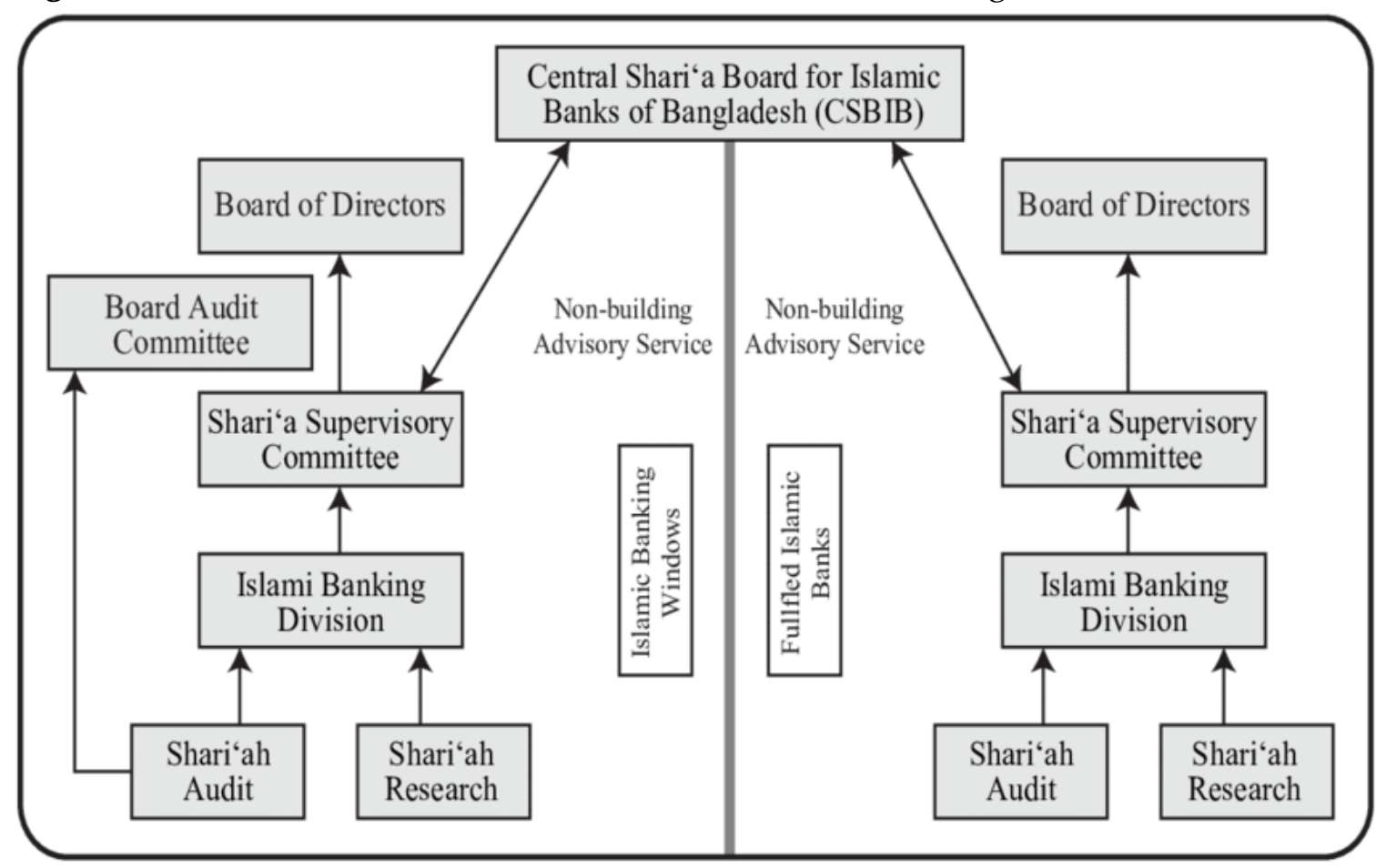

Source: Abdullah and Rahman (2017) 
From the literature, Shariah is the utmost standard followed from Quran and Sunnah for Islamic Financial Institutions (IFI). An increasing trend in the number of Islamic Banks and Islamic Banking divisions in Bangladesh raised the question whether they are complying with the Shariah in its operation. This paper has tried to assess the operational compliance from the perspective of deposits, investment, audit and other activities.

\section{Literature Review}

Banks that continue their activities as per the instructions of Islamic Shariah are called the Islamic banks and only the Shariah is the major instructing principle for performing bank's operational activities (Ahmad, 2000; Ahmad, 1984; Siddiqui, 2001, Siddiqi, 1985; Siddiqi, 1983; Khan and Mirakhor, 1986;). Shariah governance performs as an overall system controls that ensure that all the transactions and activities of Islamic financial institutions and banks comply with the principles of Shariah (Haridan, Hassan and Karbhari, 2018). Except the things explicitly forbidden by Shariah guidance, every single economic affair is permitted (Kamali, 2000).

In Shariah, interest is prohibited (Al-Quran, 2:275, 3:130, 4:161) and Islamic banks should involve in transactions that are not associated with interest (Ahmad, 2008). Studies of Chapra and Khan (2000) identified that Islamic Shariah banking system seems as interest-based products but they are not, because there are some major distinctions between the interest \& profit e.g. interest is fixed but profit is not fixed. Interest creates injustice and cruelty (burdensome for payment) that can be replaced by launching the profit-loss sharing based investment methods (e.g. Mudarabah, Musharakah etc.) that are Halal methods of conducting business ( Jalil and Rahman, 2010; Rarick, 2009; Abdul Rahman, 2007; Imam and Kpodar, 2010).

Conventional banks comprise of single layer governing body with the board of directors and executives while the Islamic banks have an additional layer as Shariah supervisory board for monitoring the Shariah related activities. The role of Shariah supervisory board is to oversee whether Islamic banks involve trading with any prohibited activity (Mollah \& Zaman, 2015).

Islamic institutions must follow a set of Shariah principles so that they can grab the general peoples' trust and confidence (Rashid et al., 2014; Ghayad, 2008; Ahmad and Haron, 2002; Laldin, 2008; Metawa \& Almossawi, 1998; Naser et al., 1999; Archer \& Karim, 2002). Shariah compliance is the key factor that ensures the trustworthiness of banks following Islamic Shariah and stimulates credence in the stakeholders specially the shareholders for selecting Islamic banks (Bhambra, 2002; Rammal, 2006). Shariah compliance ensures justice and growth in the economy (Chapra \& Ahmed, 2002). Higher 
shariah compliance helps IFIs to sustain in the market (Sori et al., 2015), on the other hand Poor Shariah compliance results in market failure (Sori et al., 2015; Hassan et al., 2017).

Although Islami banks are established to provide shariah services to the customer, the mission statement of these banks fails to communicate clearly its objectives \& goals (Ahmed et al., 2017). Some study strongly claim that there are no difference between the Islamic banks with those of the conventional banks (Yousef, 2004; Abozaid and Asyraf, 2007; Meera and Dazuljastri, 2005; and Kuran, 2004). Yusof and Fahmy (2008) has stated that the difference between Islamic and conventional banks is the use of the term "profit rate" rather than interest rate. Malik et al. (2011) claimed that financing products offered by Islamic banks generally have a closer resemblance to the debt instruments other than profit-loss partnership. Usmani (2008), has found that most of the Sukuk (bond) issued by the Islamic banks are not complying with shariah. Meera \& Larbani (2009) have confirmed that the model of Islamic bank is simply the resemblance of conventional banking which violates Shari'ah; as a result, the objectives of establishing Islamic banks fail. Ullah (2014) has found that shariah compliance in Islamic banks are in vulnerable state specially in investment activities. Again, Islamic banks claim to contribute its large portion from profit in social activities but it has been seen that recently Islamic banks have fallen drastically in regards of social reporting (Hossain \& Khatun, 2014). Although Islamic banks are thought as an ethical organization, they are found less compliance with Islamic ethics (Febianto, 2010). They comply with profit-loss sharing in theory rather than in practice (Chong and Liu, 2009; Obaidullah, 2008).

There are lots of reasons for non-compliance of shariah in Islamic banks. The major obstacle of complying with shariah is the absence of shariah framework from the regulators ( Alam et al., 2019; Ullah, 2014; Ahmad and Hassan, 2007). Alam et al. (2019) has found that the Board of Directors use the Shariah Supervisory Board in achieving their objectives. Another big problem is the lack of shariah experts who are supposed to have both conventional and shariah based banking knowledge (Malik et al., 2011; Grais and Pellegrini, 2006). Moreover, different interpretations by different scholar on a particular issue (Grais and Pellegrini, 2006; Ullah, 2012), lack of knowledge regarding shariah complaint products (Koch and Stenberg, 2010), time limitations and lack of supporting staffs of the shariah experts (Malik et al., 2011; Chapra and Khan, 2000) and Chapra \& Ahmed, 2002) are also responsible for the non-compliance.

\section{Research Objective}

The purpose of our study is to find out the current degree of Shariah compliance by Islamic banks that are conducting their business in Bangladesh. This study will try to 
assess not only the degree of Shariah compliance but also the degree of Shariah violation by the Islamic banks. Sometimes this Shariah violation is caused by the external factors but in other case it is caused because of the bank's internal limitations. So, our objective is to find out both the internal and external limitations of Islamic banks and to suggest some actions to eliminate Shariah related non-compliance for ensuring a better banking service.

\section{Research Methodology}

The study has been conducted based on the qualitative research methodology. The qualitative data for the study has been collected from both primary and secondary sources. The primary data were collected from practitioners and the regulators point of view. Practitioner's opinion was collected through field survey on the Islamic bank's employees as they are well known regarding the compliance of Shariah in deposits, investments and other activities of the bank. For questionnaire survey we selected six (6) Islamic banks out of 8 full-fledged Islamic banks as sample which is $75 \%$ of total population. The samples are selected based on convenience method as the employees of these banks can be conveniently reached due to familiarity and more insightful information might be obtained. In total 400 respondent's opinion was collected through the survey from the 6 full-fledged Islamic banks. In full-fledged Islamic banks, for survey 20-25 employees were approached in each branch of Islamic banks. This study basically targeted corporate branches of the sampled banks as they possess more information. For Islami Bank Bangladesh Limited 6 branches, for Social Islami bank Ltd (SIBL) 2 branches, for Shahjalal Islami bank Ltd (SJIBL) 2 branches, for Al-Arafa Islami bank Ltd (AIBL) 3 branches, for ICB Islami bank Ltd (ICBIBL) 2 branches and for Union bank Ltd (UBL) 3 branches were visited. Due to lack of time and accessibility, it was not possible to cover more branches. The respondents were approached graciously and explained the objective of the study so that they give their unbiased opinion to us. They were permitted to take the questionnaires at home and return it on the following day in their information desk. This gives them the opportunity to fill the questionnaire at their convenient time and at the same time their working hours or their break periods were not affected. Furthermore, employees were explained carefully that their management was not involved, and the confidentiality and anonymity of their opinions was guaranteed for reducing the probability of response favoritism. Total 425 forms of questionnaire were distributed in late December 2019 and among them 405 were collected. Among the 405 answered questionnaires, 400 were properly usable. As the response rate is about to $94 \%$, the rate can be considered as large enough as well as satisfactory for the statistical inferences. 
Table 2. Information about the Questionnaire Survey

\begin{tabular}{|c|l|c|c|c|}
\hline SL \# & Selected bank name & $\begin{array}{c}\text { Distributed } \\
\text { questionnaire }\end{array}$ & $\begin{array}{c}\text { Received \& } \\
\text { completed } \\
\text { questionnaire }\end{array}$ & $\begin{array}{c}\text { Response } \\
\text { rate }\end{array}$ \\
\hline 1 & Islami bank Bangladesh Ltd (IBBL) & 137 & 129 & $94.16 \%$ \\
\hline 2 & Social Islami bank Ltd (SIBL) & 52 & 45 & $86.53 \%$ \\
\hline 3 & Shahjalal Islami bank Ltd (SJIBL) & 54 & 51 & $94.44 \%$ \\
\hline 4 & Al-Arafa Islami bank Ltd (AIBL) & 70 & 66 & $94.28 \%$ \\
\hline 5 & ICB Islami bank Ltd (ICBIBL) & 40 & 38 & $95.00 \%$ \\
\hline 6 & Union bank Ltd (UBL) & 72 & 71 & $98.61 \%$ \\
\hline & Total & 425 & 400 & $94.11 \%$ \\
\hline
\end{tabular}

Source: Author's own constructed

The questionnaire having four sections concentrating on Shariah compliance in Deposit, Shariah compliance in Investment activities, Shariah compliance in Auditing and Other Shariah Compliance Issues were given to every respondent. 5-point Likert Scale was used for data collection as: 5-Strongly Agree, 4-Agree, 3-Neutral, 2-Disagree, 1-Strongly Disagree. Likert scale is used here as it is better able to assess the level of compliance (Sarea, Muslih and Hawaldar, 2017).

The practitioner's view regarding shariah compliance is obtained from personal interview with two Shariah Supervisory Board (SSB) members from IBBL and SIBL respectively. Due to time limitations and difficulty of accessibility, Shariah Supervisory Board members of other banks were not possible to reach. They have informed about their current actions for ensuring successful Shariah compliance. The regulators point of view was received through a personal interview on top management level's employees of Bangladesh bank. Due to time constraint of the officials, two executives of Bangladesh bank head office were interviewed to understand their initiatives regarding Shariah compliance in the operations of Islamic banks.

Secondary data was collected from Islamic banks annual report, Islamic banks websites, Qur'an, Sunnah, articles regarding Islamic Shariah, reports published on Islamic bank's performance by Bangladesh bank etc. Data were analyzed through the calculation of mean, maximum, minimum, standard deviations and data were presented through tables, chart/graphs. 


\section{Analysis of the Questionnaire Survey}

\subsection{Demographic Information of the Respondents}

Out of 400 respondents, most of them are male (94\%) as banking sector hires more male employees than female. Most of the respondents' age is between 26 to 45 (74\%).

Figure 2. Demographic Information of The Respondents
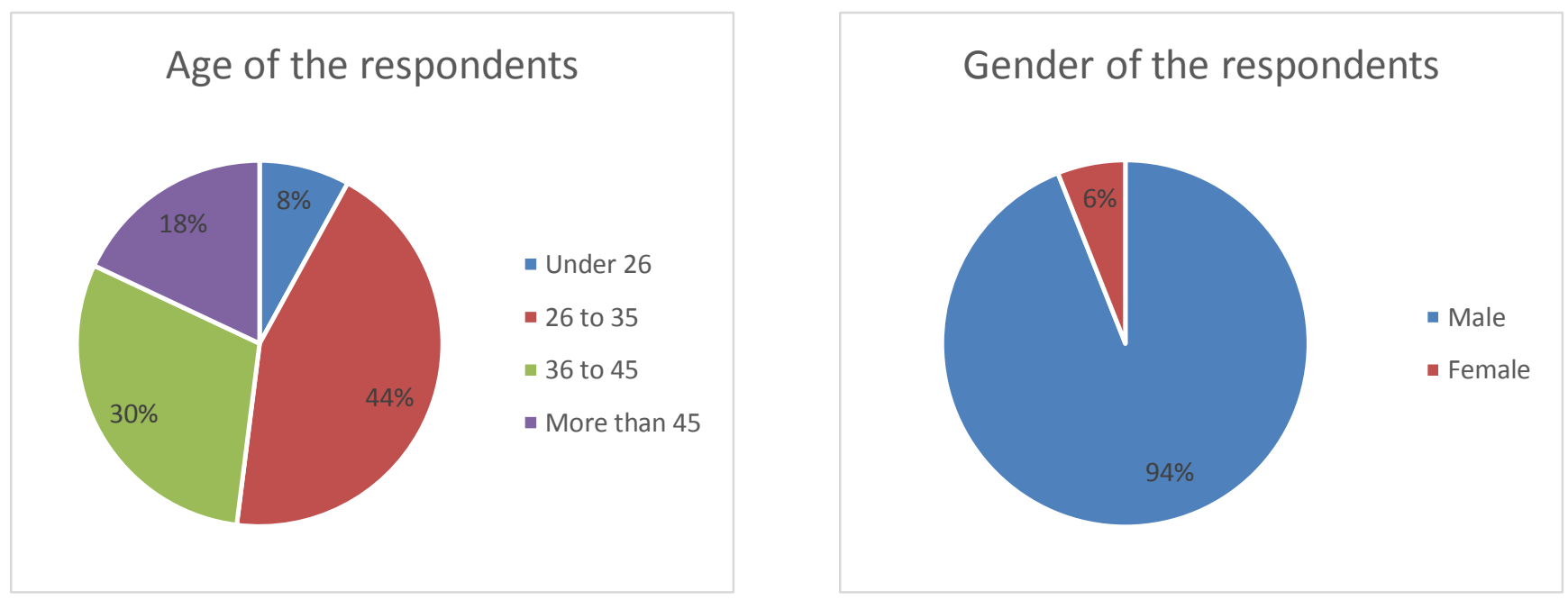

Source: Author's own constructed

\subsection{Shariah Compliance in Deposits}

The compliance level is categorized in to three type:

1. High level of compliance: Here the level of compliance is above $80 \%$.

2. Moderate level of compliance: Here, compliance is found in between $60 \%$ and $80 \%$

3. Low level of compliance: Here compliance is very low. Its below 60\% (Sarea, Muslih and Hawaldar, 2017).

Figure 3. Three Level of Compliance

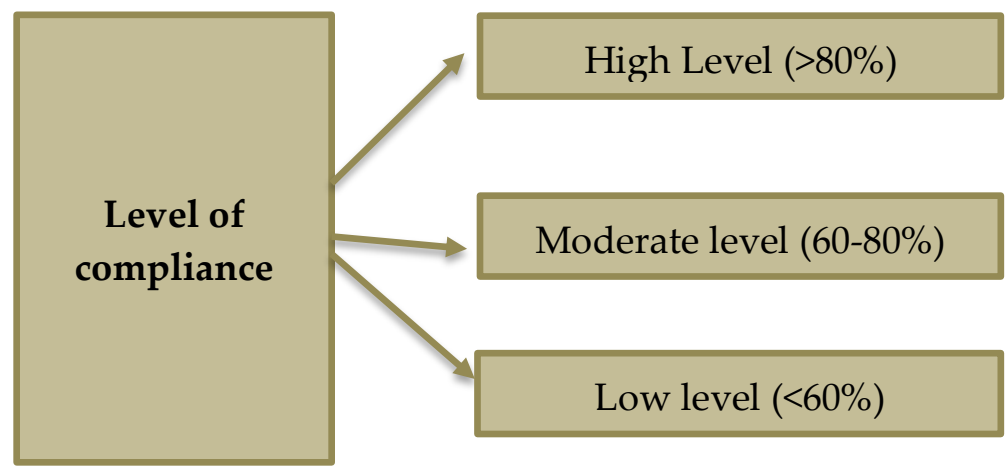

Source: Author's own constructed 
Table 3: Descriptive Statistics in Deposits Survey

\begin{tabular}{|c|c|c|c|c|c|}
\hline SL. \# & Shariah compliance in deposits: & Min & Max & Mean & SD \\
\hline Q-01 & The bank has a policy for Shariah deposit. & 4.00 & 5.00 & 4.77 & .42 \\
\hline Q-02 & The bank shares the profits with depositors. & 4.00 & 5.00 & 4.72 & .45 \\
\hline Q-03 & No fixed profit is offered to the depositors. & 3.00 & 5.00 & 3.22 & .76 \\
\hline Q-04 & $\begin{array}{l}\text { The bank is trying to comply with the Shariah } \\
\text { regarding deposits. }\end{array}$ & 3.00 & 5.00 & 4.51 & .58 \\
\hline Q-05 & $\begin{array}{l}\text { The bank has } 100 \% \text { compliance with the } \\
\text { Shariah regarding deposits. }\end{array}$ & 2.00 & 5.00 & 4.29 & .61 \\
\hline
\end{tabular}

Most of the employees believe that their banks comply the Shariah in providing deposit schemes as well as they give profit to the deposit holders. But the non-compliance can be traced from the question whether they comply 100\%, where the minimum score is 2 and standard deviation is .6134. Moreover, neutral position in the question whether their banks offer fixed profit to the depositors cast doubt regarding profit sharing principles. So, non-compliance is found from the deposit's perspective.

Figure 4. Shariah Compliance in Deposits

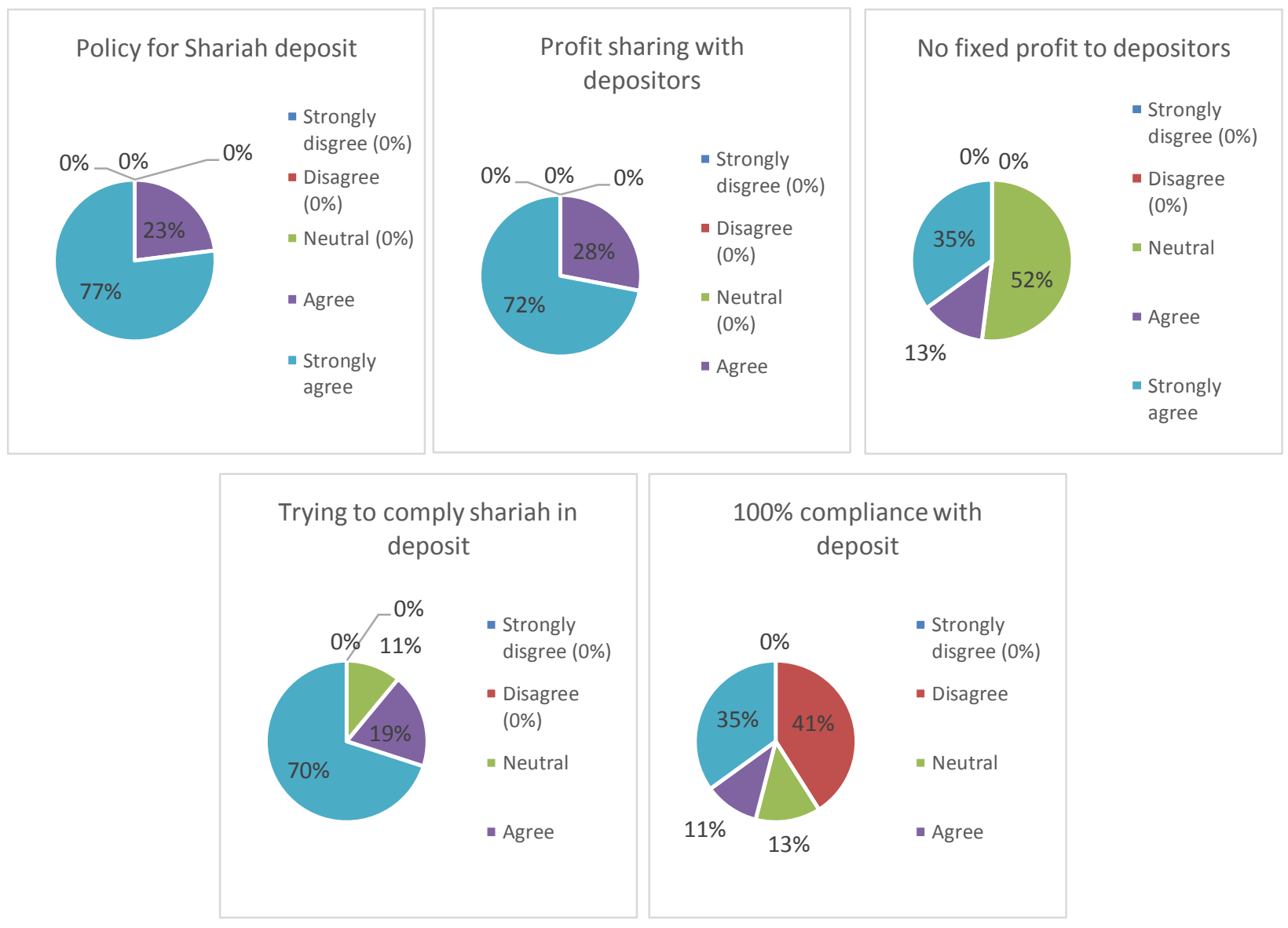


The pie chart above shows that almost all the Islami banks have policy for shariah deposits; they share profit with the depositors, and they try to comply with shariah regarding deposits. But the fact is the majority neutral position (52\%) with the statement 'no fixed profit is offered to depositors' casts doubt about the compliance with shariah deposit policy. Moreover, $41 \%$ respondents disagree with the statement that Islami banks have $100 \%$ compliance with shariah in deposit. This implies that by offering fixed profit rate in deposit, Islami banks violates shariah in deposit.

\subsection{Shariah Compliance in Investment Activities}

Table 4. Descriptive Statistics on Investment Activities Survey

\begin{tabular}{|c|c|c|c|c|c|}
\hline SL. \# & $\begin{array}{l}\text { Shariah compliance in investment } \\
\text { activities: }\end{array}$ & Min & Max & Mean & SD \\
\hline Q-01 & $\begin{array}{l}\text { The bank follows Islamic shariah in } \\
\text { Musharakah (profit-loss sharing } \\
\text { partnership). }\end{array}$ & 2.00 & 5.00 & 3.27 & .68 \\
\hline Q-02 & $\begin{array}{l}\text { The bank follows Islamic Shariah through } \\
\text { Mudarabah (venture capital). }\end{array}$ & 2.00 & 5.00 & 4.20 & .63 \\
\hline Q-03 & The bank follows Shariah in Ijarah (Lease). & 3.00 & 5.00 & 4.31 & .60 \\
\hline Q-04 & $\begin{array}{l}\text { The bank follows Shariah while providing } \\
\text { Quard Hasanah (Benevolent loan). }\end{array}$ & 3.00 & 5.00 & 4.15 & .75 \\
\hline Q-05 & $\begin{array}{l}\text { The bank has } 100 \% \text { compliance with the } \\
\text { Shariah regarding investments. }\end{array}$ & 1.00 & 5.00 & 3.55 & .87 \\
\hline
\end{tabular}

The overall average score of investment section is 3.55 which indicates the neutral position in investment activities. The minimum value (1) of $100 \%$ compliance with shariah based investment cast substantial doubt regarding the compliance in this section as well. Most of the Islamic banks do not provide investment loans following the Musharakah method as concluded from the survey where 209 (out of 400) respondents opposed to agree with the statement. The minimum value (2) of Musharakah and Mudarabah investment also support the inference. Although the ljarah related shariah compliance is mostly found, the overall compliance is not satisfactory at all. 
Figure 5. Shariah Compliance in Investments
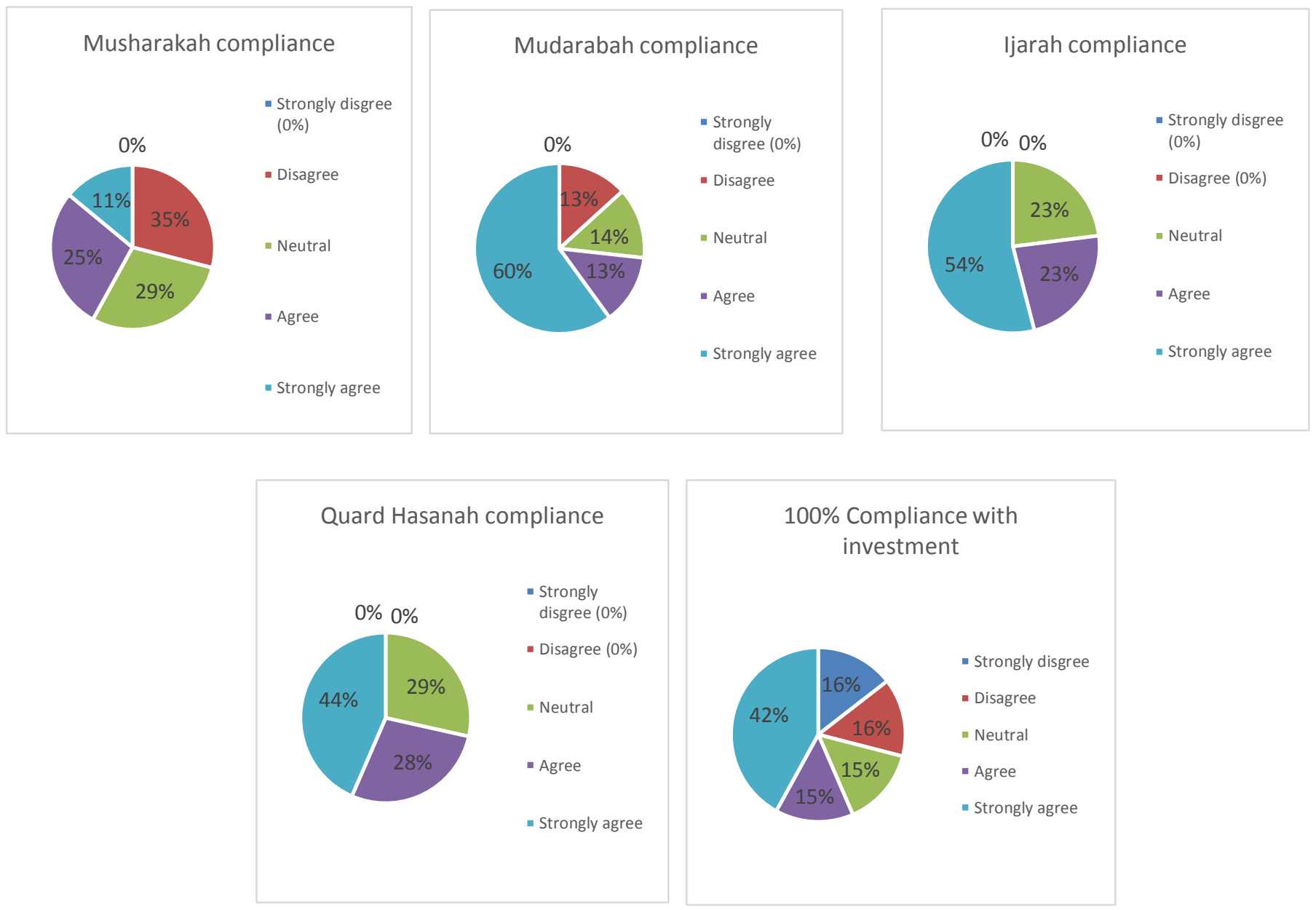

The chart above shows that most of the respondents believe that Islami banks have moderate level of compliance with Mudarabah investment (73\%), Ijarah (77\%) and Quard Hasanah (72\%) and very low level of compliance with Musharakah investment (36\%). Overall compliance with the investment is also low (57\%).

\subsection{Shariah Compliance in Auditing}

Table 5. Descriptive Statistics on Auditing Activities Survey

\begin{tabular}{|l|l|l|l|l|l|}
\hline $\begin{array}{l}\text { SL. } \\
\text { No: }\end{array}$ & Shariah compliance in auditing: & Min & Max & Mean & SD \\
\hline $\begin{array}{l}\text { Q- } \\
01\end{array}$ & $\begin{array}{l}\text { The bank has a Shariah supervisory committee } \\
\text { that overlooks the Shariah based activities. }\end{array}$ & 3.00 & 5.00 & 4.50 & .54 \\
\hline $\begin{array}{l}\text { Q- } \\
\text { 02 }\end{array}$ & $\begin{array}{l}\text { Existing internal committee is enough to ensure } \\
\text { Shariah compliance at all levels. }\end{array}$ & 1.00 & 5.00 & 3.56 & 1.38 \\
\hline \begin{tabular}{l} 
Q- \\
\hline
\end{tabular} & Branch level Shariah audit system needs to be & 3.00 & 5.00 & 4.36 & .53 \\
\hline
\end{tabular}




\begin{tabular}{|l|l|l|l|l|l|}
\hline 03 & $\begin{array}{l}\text { given more emphasis for ensuring Shariah } \\
\text { compliance of the bank. }\end{array}$ & & & \\
\hline $\begin{array}{l}\text { Q- } \\
04\end{array}$ & $\begin{array}{l}\text { The bank is audited annually based on Shariah } \\
\text { by an expert audit firm. }\end{array}$ & 1.00 & 5.00 & 3.84 & .91 \\
\hline $\begin{array}{l}\text { Q- } \\
05\end{array}$ & $\begin{array}{l}\text { The bank has 100\% compliance with the Shariah } \\
\text { regarding audit. }\end{array}$ & 1.00 & 5.00 & 2.07 & .82 \\
\hline
\end{tabular}

Although most of the banks have Shariah supervisory committee but this committee is not capable to ensure shariah compliance as the board dominates the committee (interview finding from SSB). Most of the banks have non-compliance in shariah audit as conventional statutory audit is mandatory and dual audit is cost burden for the banks. The mean score (2.07) of $100 \%$ compliance with audit related issues confirms the deduction.

Figure 6. Shariah Compliance in Auditing

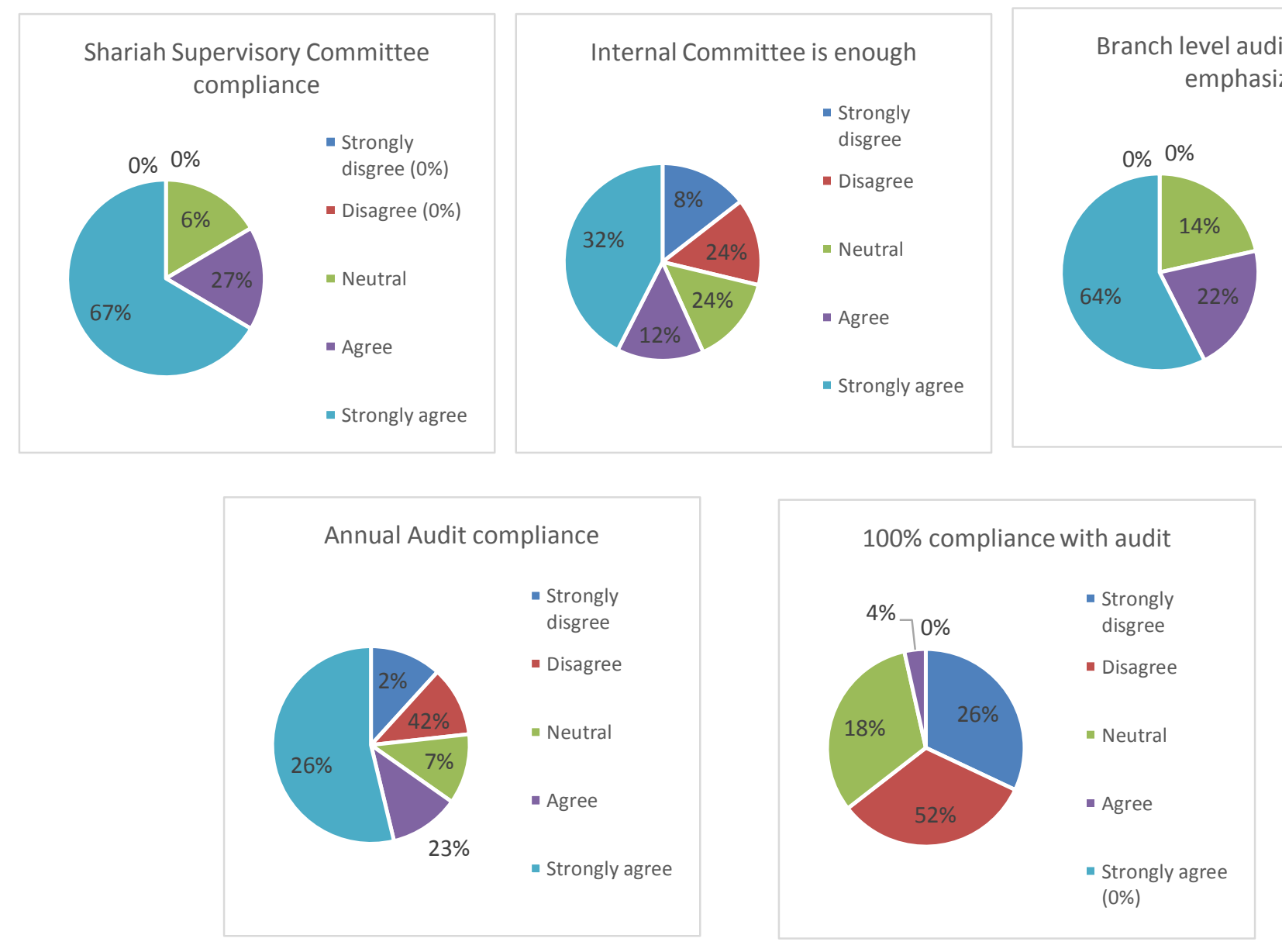


The chart indicates that most of the banks have compliance with shariah supervisory committee (SSC) and most of the respondents agree that branch level audit or supervisory activities should be given more emphasis. But the committee is not enough to ensure vigilant supervision (majority disagree and neutral position). Islami banks have server non-compliance in shariah audit (according to more than 50\% respondents) as they need to comply with conventional audit as well. There is no shariah audit firm in Bangladesh which can be blamed for that.

\subsection{Shariah Compliance in Other Issues}

To find the level of Shariah compliance in the field other than deposits, investments and Auditing, we had asked some Shariah related questions to the respondents. Then the descriptive analysis of their responses is presented below:

Table 6. Descriptive Statistics on Other Shariah Compliance Survey

\begin{tabular}{|c|c|c|c|c|c|}
\hline $\begin{array}{l}\text { SL. } \\
\text { No: }\end{array}$ & Other Shariah compliance issues & Min & Max & Mean & SD \\
\hline Q-01 & $\begin{array}{l}\text { The objective of Islamic bank establishment is } \\
\text { to offer Shariah based banking needs to } \\
\text { customer. }\end{array}$ & 3.00 & 5.00 & 4.43 & .48 \\
\hline Q-02 & $\begin{array}{l}\text { Islamic banks do not involve in Riba (interest) } \\
\text { instead it uses the method of profit-loss } \\
\text { sharing. }\end{array}$ & 1.00 & 5.00 & 4.29 & 1.02 \\
\hline Q-03 & $\begin{array}{l}\text { Islamic banks never invest in industries that } \\
\text { provide HARAM products and services (e.g. } \\
\text { alcohol, pork, gambling etc.). }\end{array}$ & 3.00 & 5.00 & 4.86 & .41 \\
\hline Q-04 & $\begin{array}{l}\text { Employees of Islamic banks have advanced } \\
\text { knowledge in Shariah. }\end{array}$ & 1.00 & 5.00 & 2.02 & .76 \\
\hline Q-05 & $\begin{array}{l}\text { Products and services provided by Islamic } \\
\text { bank are like those of conventional banks. }\end{array}$ & 1.00 & 5.00 & 1.81 & 1.28 \\
\hline Q-06 & $\begin{array}{l}\text { Only Muslim clients are attracted by Islamic } \\
\text { banks as they follow Islamic Shariah } \\
\text { compliance. }\end{array}$ & 1.00 & 3.00 & 1.86 & .67 \\
\hline Q-07 & $\begin{array}{l}\text { Shariah compliance is an obstacle for coping } \\
\text { with the interest-based economy of } \\
\text { Bangladesh. }\end{array}$ & 1.00 & 5.00 & 2.83 & 1.26 \\
\hline Q-08 & $\begin{array}{l}\text { Shariah compliance is an advantage rather } \\
\text { than impediment for a Muslim majority } \\
\text { country like Bangladesh. }\end{array}$ & 1.00 & 5.00 & 3.81 & .97 \\
\hline
\end{tabular}




\begin{tabular}{|l|l|l|l|l|l|}
\hline Q-09 & $\begin{array}{l}\text { 100 percent Shariah compliance is not } \\
\text { possible. }\end{array}$ & 1.00 & 5.00 & 2.95 & 1.36 \\
\hline Q-10 & $\begin{array}{l}\text { Higher authority gives 100 percent effort to } \\
\text { ensure Shariah compliance. }\end{array}$ & 1.00 & 5.00 & 3.35 & .88 \\
\hline Q-11 & $\begin{array}{l}\text { More training sessions are needed to provide } \\
\text { Shariah complying knowledge to increase } \\
\text { employee's efficiency level. }\end{array}$ & 3.00 & 5.00 & 4.14 & 1.18 \\
\hline Q-12 & $\begin{array}{l}\text { More Shariah based research needed to be } \\
\text { performed for the formation of new and } \\
\text { effective guidelines for Islamic banks. }\end{array}$ & 4.00 & 5.00 & 4.54 & .54 \\
\hline
\end{tabular}

Although 97\% respondents believe that Islamic banks are established to offer Shariah based banking services to their customers, mostly agreed that $100 \%$ shariah compliance in not possible in Bangladesh as the economy is interest based. In interest-based economy, depositors ask for fixed interest rate but Islamic banks can't offer fixed profit rate. Most of the Islamic banks follow interest-based model but use the term 'profit' instead (interview finding) as they offer fixed profit rate. The finding is consistent with that of Yusof and Fahmy (2008). The products offered by Islamic bank are like conventional bank (interview finding and mean score of Q-5: 1.81). Moreover, NonMuslims are also attracted by the Islamic bank customer services as the average value (1.86) supports the fact that only Muslims are attracted by the Islamic banks.

The fact is Islamic bank's employees lack Shariah related advance knowledge, which is agreed by $91 \%$ respondents (Mean value 2.02). They believe that more training and knowledge sharing session can increase their knowledge and efficiency on shariah activities (Mean score 4.14). The higher-level authority lacks enthusiasm and efforts to comply $100 \%$ with shariah which is challenging but not impossible to achieve (interview finding, mean score 3.35). Finally, mostly agreed that Shariah based study and research can play a great role in drawing the attention of the regulators of banking sector in Bangladesh (means score 4.54).

\subsection{Findings from Interview of Shariah Supervisory Board}

After having face to face conversations with Shariah supervisory board members, it is found that:

- The banks Shariah supervisory board consists of at least five (5) members having both the inside and outside members. Though the external members are being selected based on their Shariah knowledge, but the interviewees accepted that the inside members lack qualifications instructed in the AAOIFI standards such as educational background, shariah knowledge etc. 
- Every Islamic bank has specific shariah principles formed by their own Shariah Supervisory Board.

- As there is a lack of co-ordination among different banks' Shariah Supervisory Boards, there is no possibility to have a uniform guideline or reporting standard.

The interviewees think that it is a necessity for the Islamic banks to have a uniform guideline. They also agree with the fact that CSBIB and Bangladesh bank can play a great role in this regard, but they could not come up with any solution so far.

\subsection{Findings from Interview of the Regulators}

An interview with the general managers of banking regulation and policy department, Bangladesh bank revealed that Bangladesh Bank is continuously investigating the performance of the Islamic banks and they publish quarterly report on it. The report shows that Islamic banking system has extended about to three times from 2007 in more than 12 countries with 15\% of market share worldwide. Islamic Banking sector in Bangladesh has about 25\% share of the whole banking sector in case of investments and deposits (Bangladesh Bank, 2020).

The interview about their regulatory actions regarding Islamic banks' Shariah compliance revealed the following facts:

- BB does not have any strict regulatory framework that would make possible proper monitoring of the Islamic banking sector. Though they provided a guideline for the Islamic banks in 2009 describing only the modes of Islamic financing which is voluntary to comply in nature. So, Islamic banks are conducting their activities following their own Shariah board-based standard.

- Islamic banks enjoy regulatory facilities such as maintaining lower reserves in the form of liquid assets: 11 percent as opposed to 18.5 percent for conventional banks. As a result, Islamic banks have more investable funds than other types of banks. For this purpose, a steady growth has been shown over the last couple of years in term of assets, deposits, loans and advances etc. In April-June 2020 quarter, the deposits and investments have grown by $2.35 \% \& 3.05 \%$ respectively.

- In recent times more and more banks are showing their interest in converting into full-fledged Islamic bank or opening Islamic banking window because of advantages received by Islamic banks. But for the last seven years, Bangladesh bank is not giving any new licenses for the expansion of the Shariah compliant finance as they unable to regulate it with Shariah principles due to lack of resources. 
But the officers said that Bangladesh bank has long been working on a uniform Shariah law framework but could not finalize yet because of central bank's lack of enough resources and manpower needed to regulate the Islamic banking industry. But they are working to develop a uniform and complete Shariah guideline for regulating Islamic banks.

\section{Limitations of the Study}

During this study, we faced some limitations which are given below:

- Lack of depth knowledge regarding Shariah as well as Islamic Financial Institutions.

- It was very hard to manage the bank officials for the purpose of the survey and personal interview as they have a very busy schedule.

- Research on Shariah compliance of Islamic banks is a new concept and consists of a vast research area but time constraint is always a big challenge.

\section{Recommendations and Implementation Process}

Based on the research findings, some recommendations along with suggestions and implementation process are provided to the official employees, management teams, regulators and others whose spontaneous participation may ensure 100\% Shariah compliance of the Islamic banks in Bangladesh.

- Regulators (e.g. Bangladesh bank) should introduce uniform shariah guideline and should introduce penalty for non-fulfilment of the Islamic Shariah as well as rewards for ensuring full Shariah compliance.

- The higher authority of the Islami banks need to take more initiatives to increase the knowledge and dedication of the officials and other employees to maintain sound Shariah compliance as well as increasing devotion to Shariah in their personal, political and social life.

- The bank shall need to give more emphasis on the Shariah compliance of their transactions, documentations, deposits, investments, audit and all other activities.

- Islamic banks authority should arrange more training and open seminar programs incorporating their employees and clients so that both the parties can have a good knowledge about the bank's actual activities.

- Islamic banks need to recruit more Shariah knowledge-based employees. For this purpose, priority should be given to the graduates of Islamic finance. Government should take initiative to establish institutes specializing in Islamic finance. 
- Shariah compliance inspection at branch level should be given more emphasized by the Islamic banks. For that they can have a policy of weekly or monthly report as well as meeting on Shariah compliance in all its branches.

- Islamic banks must have an internal Shariah audit committee to check their internal Shariah deviations.

- The Institute of Chartered Accountants of Bangladesh (ICAB) should take initiatives to develop expertise in shariah audit and should provide license to shariah audit firm.

- A great number of study and research is needed for a sound development of Islamic banking instruments such as savings instruments, shariah audit procedure, cash waqf, sukuk, Islamic credit card, debit card etc.

\section{Conclusion}

Shariah compliance at all level is a key function for the Islamic banks around the world. From a survey of 400 employees of Islamic banks and interview with Shariah Supervisory Board member and Bangladesh Bank officials it is found that Islamic banks in Bangladesh have non-compliance in Shariah with respect to fixed deposits, Musharakah investment and shariah audit. If the higher authority is devoted and determined enough then they can ensure full Shariah compliance and can provide better Shariah services to their clients and customers. Islamic banks management and Shariah supervisory bodies may have knowledge from this study about their limitations and gap regarding Shariah compliance and they may take initiatives to resolve their limitations at branch level as well as in corporate level. Compliance of the Islamic Shariah successfully can help the organization to advance their business and customer services to a saturated level of customer satisfaction. Again, Shariah compliance system in Bangladesh is generally based on deliberate initiatives by the banks. The degree of Shariah compliance can further be accelerated by Bangladesh bank and other concerned regulators by introducing laws and guidelines on operational model. BB can also empower the CSBIB so that it can oversee as well as monitor the Shariah supervisory committee's activities and auditing activities of Islamic banks. This study may draw the attention of the regulators and the concern parties to make a revised and enforceable guideline that will ensure $100 \%$ Shariah compliance. Researchers may find the issues rose in this study as useful for their further study to help the sector to develop smoothly. They can evaluate Shariah compliance level at the Islamic Shariah "windows" in the traditional interest-based conventional banks as well as a comparative study regarding the Shariah compliance of the full-fledged Islamic banks and conventional interest-based banks having Islamic banking branches or "windows". 


\section{References}

Abdullah, M. F., \& Rahman, A. (2017). Shariah governance of Islamic banks in Bangladesh Issues and challenges. Journal of Islamic Economics, Banking and Finance, 13(3), 82-94.

Abdul Rahman, A. R. (2007). Islamic banking and finance: between ideas and realities. The International Islamic University Malaysia Journal of Economics and Management, 15(2), 123-141.

Abozaid, A., \& Asyraf, W. D. (2007). The challenges of realizing maqasid al-shariah in Islamic Banking and Finance. International Conference on Islamic Banking and Finance Research and Development, IIUM, Malaysia.

Ahmad, A. U. F., \& Hassan, M. K. (2007). Regulation and performance of Islamic banking in Bangladesh. Thunderbird International Business Review, 49(2), 251-277.

Ahmed, I., Nawaz M. M., Danish, R. Q., Usman A., Shaukat, M. Z. (2017). Objectives of Islamic banks: a missive from mission statements and stakeholders' perceptions. Journal of Islamic Accounting and Business Research, 8(3). doi: 10.1108/JIABR-08-20140028

Ahmad, K. (2000). Islamic finance and banking: the challenge and prospects. Review of Islamic Economics, 9(1), 57-82.

Ahmad, N., \& Haron, S. (2002). Perceptions of Malaysian corporate customers towards Islamic Banking Products and Services. International Journal of Islamic Financial Services, 3(4).

Ahmad, Z. (1984). Concept and Models of Islamic banking: An Assessment. Paper presented at the Seminar on Islamization of Banking, Karachi.

Alam, M. K., Rahman, S. A., Mustafa, H., Shah, S. M., \& Hossain, M. S. (2019). Shariah Governance Framework of Islamic Banks in Bangladesh: Practices, Problems and Recommendations. Asian Economic and Financial Review, 9(1), 118-132. DOI: 10.18488/journal.aefr.2019.91.118.132

Al Baraka Bank, (2004). Principles of Islamic banking. [online] [Accessed 03 February 2020]. https://www.al-baraka.com/en/IslamicBanking/PrinciplesOfIslamicBanking

Archer, S., \& Karim, R. A. A. (2002). Islamic Finance Innovation and Growth. Euro-money Books and AAOIFI, London.

Bangladesh Bank, (2014). Developments of Islamic Banking in Bangladesh. April-June 2014, Research Department, Bangladesh. 
Bangladesh Bank, (2020). Developments of Islamic Banking in Bangladesh. April-June 2020, Research Department, Bangladesh.

Bank Negara Malaysia, (2010). Shariah governance framework for Islamic financial institutions. (BNM/RH/GL 012-3). Kuala Lumpur: Bank Negara Malaysia.

Bhambra, H. (2002). Supervisory Implications of Islamic Finance in the Current Environment. In Archer, S., \& Karim, R. A. A. (Eds), Islamic finance: the Regulatory challenge, John Willey, Singapore, pp. 198-212.

BMB Islamic, (2011). Global Islamic Finance Report (GIFR). BMB Islamic UK Limited, London

BNM, (2013). Islamic financial service act 2013 (IFSA 2013). Kuala Lumpur: Bank Negara Malaysia.

Chapra, M. U. (1992). Islam and Economic Challenges. The Islamic Foundation, Leicester.

Chapra, M. U., \& Ahmed, H. (2002). Corporate governance in Islamic financial institution. Occasional Paper No. 6, Islamic Research and Training Institute, Islamic Development Bank, Jeddah.

Chapra, M. U., \& Khan, T. (2000). Regulation and supervision of Islamic Banks. Occasional Paper No. 3, Islamic Research and Training Institute, Islamic Development Bank, Jeddah.

Chong, B. S., \& Liu, M. H. (2009). Islamic banking: interest-free or interest-based? PacificBasin Finance Journal, 17(1), 125-144, available at: http://dx.doi.org/10.1016/j.pacfin (accessed June 11, 2020).

Choudhury, M. A., \& Hoque, M. Z. (2006). Corporate governance in Islamic Perspective. Corporate Governance, 6, 116-128.

Febianto, I. (2010). The ethical perspective on the practices of Islamic Banking. available at: http://papers.ssrn.com/sol3/papers.cfm?abstract_id_1672140 (accessed June 09, 2020).

Ghayad, R. (2008). Corporate governance and the global performance of Islamic banks. Humanomics, 24(3), 207-216.

Grais, W., \& Pellegrini, M. (2006). Corporate governance and Shari'ah compliance in institutions offering Islamic Financial Services. Working Paper 4054, November, World Bank Policy Research. 
Haridan, N. M., Hassan, A. F. S., \& Karbhari, Y. (2018). Governance, religious assurance and Islamic banks: Do Shariah boards effectively serve? Journal of Management and Governance, 22, 1015-1043. https://doi.org/10.1007/s10997-018-9418-8

Hassan, A. F. S. (2012). An empirical investigation into the role, independence and effectiveness of Shariah boards in the Malaysian Islamic Banking Industry. PhD Thesis, Cardiff University.

Hassan, M. K., Ullah M. H., \& Khanam, R. (2017). Case studies of Shariah governance practices in Bangladesh. Conference Paper. Available from http://research.usc.edu.au/vital/access/manager/Repository/usc:25050. (Accessed June 11, 2020)

Hossain, M. M., \& Khatun, M. (2014). Disclosure Compliance of Islamic Banks in Bangladesh: Local and International regulatory perspective. Journal of Islamic Economics, Banking and Finance, 10(4), 74-88.

Imam, P., \& Kpodar, K. (2010). Islamic banking: how has it diffused? IMF Working Paper No. 10195, International Monetary Fund, African Department, available at: www.imf.org/external/pubs/ft/wp/2010/wp10195.pdf (accessed June 11, 2020).

Ismail, A. H. (2002). The Deferred Contracts of Exchange: Al-Quran in Contrast with the Islamic Economist's Theory on Banking and Finance. Institute of Islamic Understanding Malaysia (IKIM), Kuala Lumpur.

Iqbal, M., Ahmad A., \& Khan, T. (1998). Challenges facing Islamic Banking, Islamic Research and Training Institute, Islamic Development Bank. Occasional Paper No. 1, (1st ed.), ISBN: 9960-32-065-0.

Jalil, M. A., \& Rahman, M. K. (2010). Financial transactions in Islamic Banking are viable alternatives to the conventional banking transactions. International Journal of Business and Social Science, 1(3), 219-233.

Kamali, M. H. (2000). Principles of Islamic Jurisprudence. Cambridge: The Islamic Texts Society.

Kamali, M. H. (2006). Legal Maxims and other Genres of Literature in Islamic Jurisprudence. Arab Law Quarterly, 20(1), 77-101.

Khan, M. F. (2007). Setting standards for Shariah application in the Islamic financial industry. Thunderbird International Business Review, 49(3), 285-307.

Khan, M. S. (1986). Islamic interest-free banking. IMF Staff Papers, 33, 1-27. 
Khan, M. S., \& Mirakhor, A. (1986). The framework and practices of Islamic Banking. Finance Development, 3, No. September, 32-36.

Khan, M. S., \& Mirakhor, A. (1989). Islamic banking: experiences in the Islamic Republic of Iran and Pakistan. IMF Working Paper No. WP/89/12. International Monetary Fund, Washington DC.

Koch, C., \& Stenberg, L. (2010). The EU and the GCC: Challenges and Prospects under the Swedish EU Presidency. Gulf Research Center, ISBN 978-9948-490-01-2, United Arab Emirates, Dubai.

Kuran, T. (2004). Islam and Mammon: The Economic Predicaments of Islamism. Princeton University Press, NJ.

Laldin, M. A. (2008). Roles and responsibilities of Shari'ah scholars in Shari'ah advisory services series-part 1 of 2 . The Halal Journal, Vol. 11 September-October, 54-56.

Malik, M. S., Malik, A., \& Mustafa, W. (2011). Controversies that make Islamic banking controversial: an analysis of issues and challenges. American Journal of Social and Management Sciences, doi: 10.5251/ ajsms.2011.2.1.41.46

Meera, A. K. M., \& Dzuljastri, A. R. (2005). Islamic home financing through Musharakahh Mutanaqisah and Al-bai Bithaman Ajil contracts: comparative analysis. Journal of The International Association for Islamic Economics, 9(2).

Meera, A. K. M., \& Larbani, M. (2009). Ownership effects of fractional reserve system. Humanomics, 25(4), 101-116.

Metawa, S. A., \& Almossawi, M. (1998). Banking behaviour of Islamic bank customers: perspectives and implications. International Journal of Bank Marketing, 16(7), 299313.

Miah, M. D., \& Suzuki, Y. (2020). Murabaha syndrome of Islamic banks: a paradox or product of the system? Journal of Islamic Accounting and Business Research, 11(7), 1363-1378. https://doi.org/10.1108/JABR-05-2018-0067

Nabi, M. G., Islam, M. A., Bakar, R., \& Akter, A. (2015). Islamic Banking in Bangladesh: Current Status, Challenges and Policy Options. Thoughts of Economics, 25, 49-72.

Naser, K., Jamal A., \& Al-Khatib, L. (1999). Islamic banking: a study of customer satisfaction and preferences in Jordan. International Journal of Bank Marketing, Vol. 17(3), 135-150.

Obaidullah, M. (2008). Islamic Finance for Micro and Medium Enterprises. Center for Islamic Banking, Finance and Management, University Brunei Darussalam. 
Omar, A. M. (2010). Dictionary of Holy Qur'an, NOOR foundation-international, 2nd Ed. Library of Congress Control No.: 2005298281, Reprinted in February 26.

Rammal, H. G. (2006). The importance of Shariah supervision in Islamic financial institutions. Corporate Ownership and Control, 3(3), 204-208.

Rarick, C. A. (2009). Islamic finance: an alternative in the global financial market? Social Science Research Network, available at: http://ssrn.com/abstract_1332793 (accessed June 11, 2020).

Rashid, M., Hassan, M. K., \& Ahmad, A. U. F. (2014). Quality perception of the customers towards domestic Islamic banks in Bangladesh. Journal of Islamic Economics, Banking and Finance, 5(1), 109-131.

Rosly, S. A., \& Bakar, M. A. A. (2003). Performance of Islamic and mainstream banks in Malaysia. International Journal of Social Economics, 30(12), 1249-1265.

Sarea, A. M., Muslih, A. M., \& Hawaldar, I. T. (2017). Measuring the Level of Compliance with Financial Accounting Standard No. 8: Evidence from Bahrain. Proceedings of the Global Conference on Business and Economics Research (GCBER) 14-15 August 2017, Universiti Putra Malaysia, Malaysia

Sarker, A. A. (2005). Islamic Banking in Bangladesh: Achievements and Challenges. Journal of Islamic Economics. Banking and Finance, 1(1). available at: http://www.ibtra.com/pdf/journal/v1_n1_article5.pdf (accessed 08 March 2020).

Siddiqi, M. N. (1983). Issues in Islamic banking. The Islamic Foundation, Leicester.

Siddiqi, M. N. (1985). Partnership and profit-sharing in Islamic law. The Islamic Foundation, Leicester.

Siddiqi, M. N. (2006a). Shari'ah, Economics and the Progress of Islamic Finance: The Role of Shari'ah Experts. Concept paper presented to stimulate discussion at the Pre-Forum Workshop on Select Ethical and Methodological Issues in Shari'ahCompliant Finance, 21 April, Seventh Harvard Forum on Islamic Finance, Cambridge, MA.

Siddiqi, M. N. (2006b). Islamic banking and finance in theory and practice: a survey of state of the art. Islamic Economic Studies, 13(2).

Siddiqui, S. H. (2001). Islamic banking: true modes of financing? New Horizon, May-June.

Sori, Z. M., Mohamad, S., \& Shah, M. E. (2015). Shariah governance practices in Malaysian Islamic financial institutions, 1-15. Available from https://ssrn.com/abstract=2579174 or http://dx.doi.org/10.2139/ssrn.2579174. 
Ullah, M. H. (2013). Accounting and Reporting Practices of Islamic Banks in Bangladesh. M. Phil Thesis, University of Chittagong, Bangladesh.

Ullah, M. H. (2014). Shari'ah compliance in Islamic banking: An empirical study on selected Islamic banks in Bangladesh. International Journal of Islamic and Middle Eastern Finance and Management, 7(2), 182-199

Ullah, S. (2012). Fatwa Repositioning: The Hidden Struggle for Shari'ah Compliance within Islamic Financial Institutions. University of Southampton, UK.

Usmani, M. T. (2008). Sukuk and their contemporary applications. available at: www.iefpedia.com (accessed 12 January 2020).

Yusof, E., \& Fahmy, E. (2008). Are Islamic banks in Malaysia really 'Islamic'? MPRA Paper No. 20901, available at: http://mpra.ub.uni-muenchen.de/20901/ (accessed June 10, 2020).

Yousuf, S., Islam M. A., \& Islam, M. R. (2014). Islamic Banking Scenario of Bangladesh. Journal of Islamic Banking and Finance, 2(1), 23-29.

Zaher, T. S., \& Hassan, M. K. (2001). A comparative literature survey of Islamic finance and banking. Financial Markets, Institutions E Instruments 10(4), 155-199.

Zaman, M., Hudaib, M., \& Haniffa, R. (2011). Corporate governance quality, audit fees and non-audit fees. Journal of Banking Finance \& Accounting, 38, 165-197. 